\title{
Learning Outcomes for Environmental and Sustainable Development Component in the Field of Civil Engineering
}

\author{
Shahrom Md Zain ${ }^{1}$, Wan Hamidon Wan Badaruzzaman ${ }^{1}$, Riza Atiq O. K. Rahmat ${ }^{1}$, Othman Jaafar ${ }^{1}$, Noor Ezlin \\ Ahmad Basri ${ }^{1} \&$ Hassan Basri ${ }^{1}$ \\ ${ }^{1}$ Department of Civil \& Structural Engineering, Faculty of Engineering \& Built Environment, Universiti \\ Kebangsaan Malaysia, Selangor, Malaysia \\ Correspondence: Shahrom Md Zain, Department of Civil \& Structural Engineering, Faculty of Engineering \& \\ Built Environment, Universiti Kebangsaan Malaysia, 43600 UKM Bangi, Selangor, Malaysia. Tel: \\ 60-3-8921-8338. E-mail: smz@eng.ukm.my
}

$\begin{array}{lc}\text { Received: October 5, } 2012 & \text { Accepted: November 7, } 2012 \quad \text { Online Published: November 30, } 2012 \\ \text { doi:10.5539/ass.v8n16p153 } & \text { URL: http://dx.doi.org/10.5539/ass.v8n16p153 }\end{array}$

\begin{abstract}
The Department of Civil \& Structural Engineering (JKAS), Faculty of Engineering \& Built Environment, has prescribed program outcomes (POs) that include environmental and sustainable development components (ASPL) to meet the requirements put forth by the Engineering Accreditation Council (EAC). Two programs are offered to students: the Civil \& Structural Engineering Program and the Civil \& Environmental Engineering Program. Therefore, the relevant courses are compulsory to prepare the Course Outcomes (COs) in accordance with teaching plans and to measure to what extent students have achieved the specified POs. This paper discusses the assessment and relationship between COs and POs for the ASPL component made within three specific courses at JKAS, which aims to determine the suitability of the ASPL component by correlating measurements of COs and POs of related courses. It is important to develop the best possible ASPL component measurement model for both study programs offered in JKAS.
\end{abstract}

Keywords: learning outcomes, course outcomes COs, program outcomes POs, environmental and sustainable development component (ASPL), civil engineering

\section{Introduction}

Sustainable development is a concept that emphasizes the conservation and preservation of natural resources. It is comprehensive and is therefore not limited to certain activities, and it is closely related to the continuation of human life on earth. Sustainable development concerns three primary categories: economic, social, and environmental. These three elements are interconnected to create security, harmony, and prosperity. Sustainable development seeks to balance human needs and demands with the environment's capacity to cope with human consumption and industry. Today, environment and sustainable development component (ASPL) is an important curricular component in higher education, which aims to create human capital that meets the needs of the job market and works to preserve the earth's finite resources. It covers all areas of education. Our country needs engineers, scientists, and those who are experts in various fields to jointly assist in sustaining national development, which not only depends on the earth's resources but also on worker's skills and expertise to preserve those resources. How can ASPL education achieve its desired goals, and how can we measure its effectiveness? Discussions concerning APSL in tertiary education are being held at the national and international levels. Keene and Blumstein (2010) argue that changing environmental education requires the cooperation of various organizations and academic disciplines.

The National Higher Education Strategic Plan, which was launched in 2007, prioritizes the transformation of higher education. The plan aims to achieve excellence and sustainability in higher education beyond the year 2020 (Ministry of Higher Education, 2011) and outlines seven main foci related to that goal. Among the plan's stated goals is the effort to improve the quality of teaching and learning to produce innovative and ethical individuals with the capacity to think critically and who are committed to a common moral standard. To this end, educational practice has been transformed to focus on outcomes. Outcomes-based education (OBE) endeavors to improve the quality of teaching and learning to meet or exceed international standards. For example, to achieve international recognition of credit equivalency, engineering programs in Malaysia must meet certain standards 
before the country is offered membership in an agreement such as the Washington Accord. According to the OBE approach, the measurement of student learning outcomes is needed to determine students' competencies and cumulative grade point averages (CGPA) for each semester. There are various approaches being used by educational institutions in Malaysia to improve the evaluation of student outcomes. Among them is the development of an electronic evaluation system (Aishah, 2010).

The Department of Civil \& Structural Engineering, Faculty of Engineering \& Built Environment, at Universiti Kebangsaan Malaysia (UKM) offers two study programs for undergraduates: the Civil \& Structural Engineering Degree Program (KA) and Civil \& Environmental Engineering Degree Program (KS). The programs being offered are recognized by the Engineering Accreditation Council (EAC), Board of Engineers, Malaysia. Based on engineering program requirements, EAC (2007) has prescribed two program outcomes (POs) related to environment and sustainable development:

1) Understanding of the principles of design for sustainable development.

2) Understanding of the social, cultural, global and environmental responsibilities of a professional engineer.

The Department of Civil \& Structural Engineering (JKAS) has outlined 10 program outcomes (POs) that must be achieved by students (Table 1) and two components related to the environment and sustainable development in the PO3. Each course has a specified expected course outcome (CO), and each $\mathrm{CO}$ contributes to the achievement of its program's required outcomes (POs). The method for measuring the COs and POs in JKAS is still being improved to suit the needs of each course. Table 1 shows that the outline in PO3 is only for courses in civil engineering design and structure, or civil engineering and environment with environmental constraints and sustainability. Thus, there are courses that do not have an outline in the POs as additions to the environment and sustainable development. This paper discusses examples of PO3 made for the evaluation of three JKAS courses offered in the 2010/1011 sessions: KKKH4284 Sustainable Urban Planning; KKKH4254 Project Design II; and KKKW4024 Pollution Control. This aim is to determine the suitability of PO3 assessment COs for related courses. Evaluations of COs and POs attracted the attention of the EAC panel during their 2010 assessment visits. Therefore, the method for measuring COs and POs must be improved to better assess student achievement.

Of course, students' successful achievement of COs and POs reflects well on an institutions' teaching practices, but this is not the main goal of the assessments. Indeed, the primary aim is to produce graduates who are prepared to help the country continue national development by sustainable means. ASPL teaching and learning in UKM does not take place solely in class but is also included in outdoor activities related to the daily lives of students who seek to enhance their awareness of environmental conservation and sustainable development (Shahrom et al., 2011).

Table 1. Program outcomes (pos) for civil \& structural engineering degree program and civil \& environmental engineering degree program

\section{Program Outcomes, PO}

PO1 Ability to acquire and apply mathematical, science, and engineering principles toward technical competency in the fields of Civil \& Structural Engineering/Civil \& Environmental Engineering

$\mathrm{PO} 2$ Ability to identify engineering problems and formulate a solution.

PO3 Ability to design a Civil \& Structural Engineering project/Civil \& Environmental Engineering within realistic limitations, including economic, environmental, social, political, ethical, health, and security and sustainability.

PO4 Professional understanding and ethical responsibility and commitment.

PO5 Ability to plan and conduct an experiment and then to analyze and interpret the data collected.

PO6 Ability to use techniques, skills and modern technique tools entailment for engineering practice.

PO7 Ability to communicate effectively, not only with other engineers but also with society at large.

PO8 Ability to function effectively as an individual in groups and to lead or manage a group or teammates effectively.

PO9 Commitment to lifelong learning.

PO10 Ability to use elements in construction project management, asset management, public policy, administration, business, and entrepreneurship. 


\section{KKKH4283 Sustainable Urban Planning}

This course is an elective course, available to students in both programs, which aims to foster comprehension of the core concepts related to sustainable urban planning, as outlined in Agenda 21 (Faculty of Engineering \& Built Environment, 2010). It covers the fundamentals of urban design in the eastern and western hemispheres. Students are also introduced to the use of modern tools in urban planning, for example, layers and satellite technology in mapping. Table 2 shows the relationship between POs, domains, and indicators used to determine the PO assessment for this course. Table 3 shows a complete assessment of this course, which takes into consideration the COs and POs, domains, indicators used, and the method of assessment (assignment- 15\%, project- $40 \%$, and final examination- $45 \%$ ). While Figure 1 shows the use of cognitive domains (K), Affective (A) and Psychomotor $(\mathrm{P})$ are based on the level of 1 to 6 following types of domains such as those used in Table 2 .
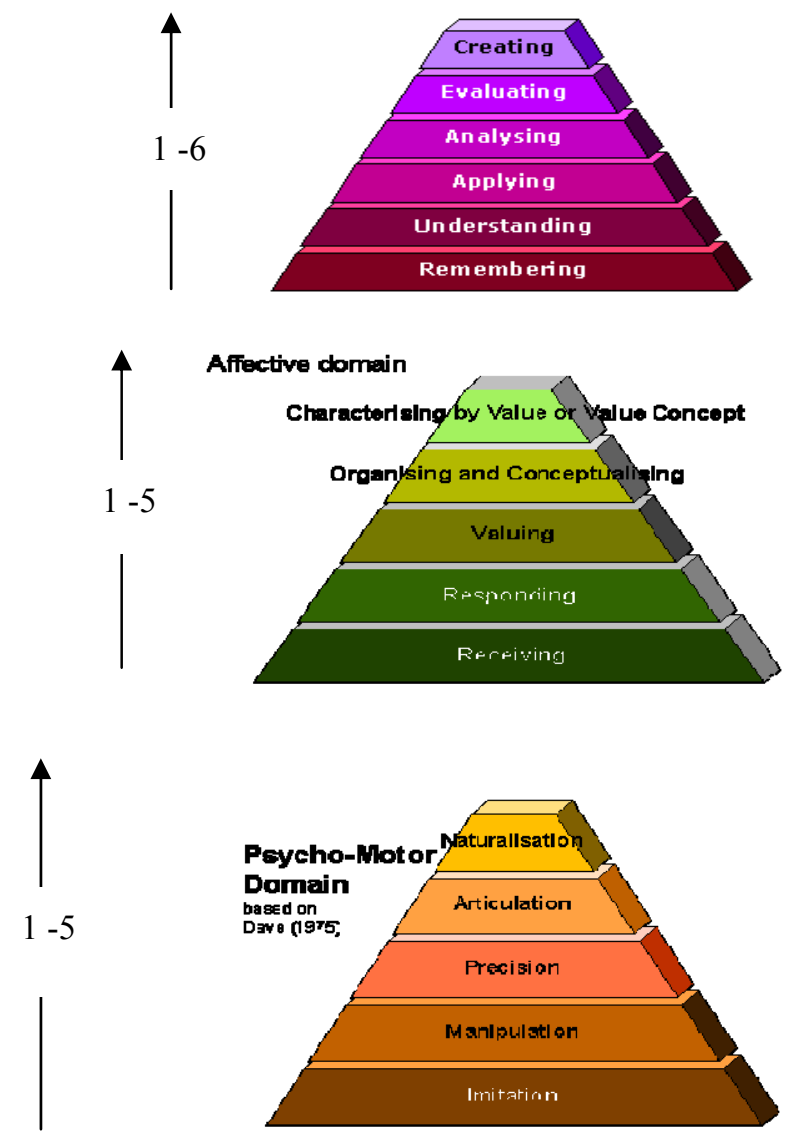

Figure 1. Cognitive Domains (K: 1-6); Affective (A: 1-5); Psychomotor (P:1-5)

Source: http://www.learningandteaching.info/learning/bloomtax.htm

ASPL components evaluated in PO4 (Assignment 1, 2, 3 and Project) use a second indicator that is able to show professional integrity required by the profession. There are three COs that outline the ASPL components:

1) Ability to assess the sustainability of cities by Local Agenda 21 (CO1)

2) Ability to assess the best practice in sustainable urban planning $(\mathrm{CO} 2)$

3) Ability to produce and present a proposal of an existing traditional urban development for a period of 30 years based on the concept of sustainable cities (CO4)

Evaluation and measurement conducted in this course shows that $\mathrm{CO} 1, \mathrm{CO} 2$, and $\mathrm{CO} 4$ contributed to the achievement of $\mathrm{PO} 4$ measurements involving assignments and projects. 
Table 2. Program outcomes (POs), domains and indicators

\begin{tabular}{|c|c|c|}
\hline $\mathrm{PO}$ & Domains & Indicator \\
\hline \multirow[t]{2}{*}{ PO1 } & Cognitive & 1.1 Ability to use basic skills to resolve engineering problems (basic courses) \\
\hline & & 1.2 Ability to use engineering knowledge (department courses) \\
\hline \multirow[t]{3}{*}{$\mathrm{PO} 2$} & Cognitive & 2.1 Ability to identify and accurately synthesize a problem \\
\hline & & 2.2 Ability to generate evidence and data that precisely and comprehensively support. \\
\hline & & 2.3 Ability to generate decisions and present solutions \\
\hline \multirow[t]{3}{*}{ PO3 } & Cognitive & 3.1 Ability to see a project from various disciplinary perspectives \\
\hline & & 3.2 Ability to integrate various disciplines into a project \\
\hline & & 3.3 Ability to produce complex public engineering designs \\
\hline \multirow[t]{5}{*}{ PO4 } & Cognitive & 4.1 Ability to display courteous and suit with need \\
\hline & & 4.2 Ability to demonstrate professional integrity as required by the profession \\
\hline & & 4.3 Ability to execute responsibilities with integrity and trustworthiness \\
\hline & & 4.4 Ability to improve self, based on comments received \\
\hline & & 4.5 Ability to manage time and be punctual \\
\hline \multirow[t]{5}{*}{ PO5 } & Psychomotor & 5.1 Ability to design an experiment based on the objective of the study \\
\hline & & 5.2 Ability to observe and collect data \\
\hline & & 5.3 Ability to analyze data \\
\hline & & 5.4 Ability to present data in graphic forms \\
\hline & & 5.5 Ability to interpret data critically \\
\hline
\end{tabular}

5.6 Ability to make inferences such as a conclusion and explain things that occurred during an experiment

PO6 Psychomotor 6.1 Ability to use modern tools

6.2 Ability to use modern methods

6.3 Ability to use modern software

PO7 Affective 7.1 Ability to verbally communicate substantiated ideas in a well-organized, smooth, and appropriately toned presentation

7.2 Ability to communicate ideas clearly in a written document that is well-organized, smooth, and appropriate

7.3 Ability to make presentations with confidence and to effectively and consistently use technology(language, symbols and visual) to support presentations

PO8 Affective 8.1 Ability to build teamwork to achieve the same objective(build rapport, interact with other people, and work effectively with them)

8.2 Ability to both lead and follow.

8.3 Ability to respect the views, positions, and beliefs of others

8.4 Ability to plan and manage

8.5 Ability to provide direction and delegation

PO9 Affective 9.1 Ability to independently explore issues/problems that need solutions.

9.2 Ability to determine whether information obtained adequately supports a conclusion

9.3 Ability to incorporate information to make decisions and solutions

9.4 Ability to use the Internet effectively

PO10 Cognitive $\quad 10.1$ Ability to plan activities in a systematic manner

10.2 Ability to structure the activities and tasks assigned

10.3 Ability to ensure the implementation of the task/performance in accordance with the plans/goals/objectives

10.4 Ability to generate an idea, proposal, and plan while taking into account many options and alternatives 
Table 3. A full assessment of the KKKH4283 sustainable urban planning course, which takes into account the $\mathrm{CO}, \mathrm{PO}$, domains, indicators and assessment methods

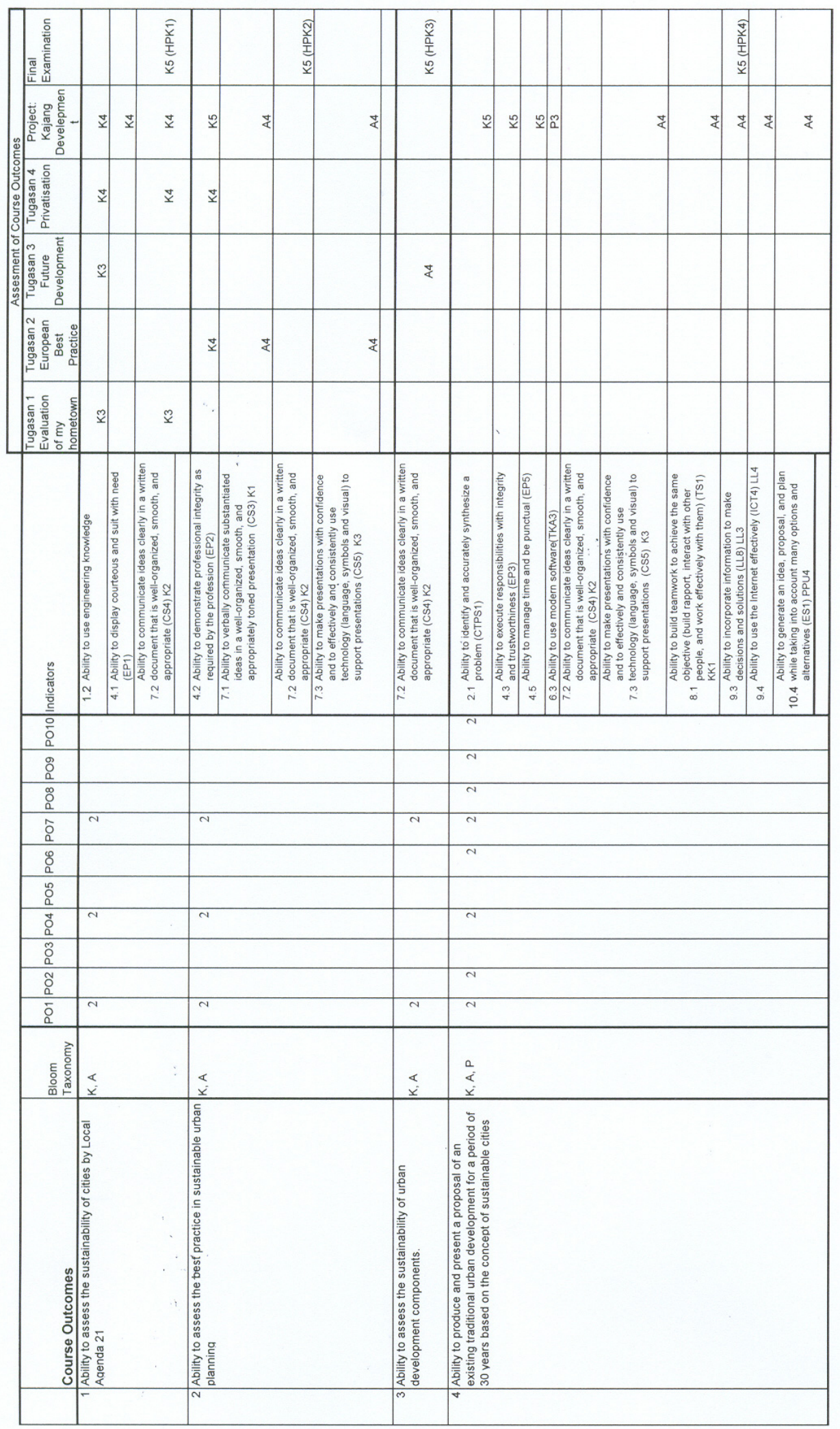




\section{KKKH4254 Integration Design Project II}

This course is compulsory for both programs in JKAS. It is a continuation of the Integrated Design I course, which aims to provide the skills and knowledge needed in engineering design. Students also learn how to prepare bids for civil engineering construction projects (Faculty of Engineering \& Build Environment, 2010). This course is conducted by two lecturers who possess a professional engineer in civil engineering. Students are required to analyze, design, and prepare engineering drawings of various components such as land, retaining walls, building structures, roads and drainage, irrigation systems, water supply systems, and sewerage systems. It covers the preparation of structural design and drawings of the foundation, floor layout, details of the floor, beams, pillars, and roof of the building. The students are divided groups comprising 4-5 members; each group is given a different construction design project related to one of the following construction projects:

1) Sek Men Puncak Jalil

2) Sekolah Agama MAWIP

3) Renovation: Hospital Universiti Kebangsaan Malaysia

4) Pusat BioInovasi, Nilai

Table 4. Relationship between CO and PO for the KKKH4254 integration design project II course

\begin{tabular}{|c|c|}
\hline Course Outcomes, CO & Program Outcomes, $\mathrm{PO}$ \\
\hline $\begin{array}{l}\text { CO1: Ability to evaluate the project site, identify problems and constraints, } \\
\text { and propose concepts and solutions }\end{array}$ & $\mathrm{PO} 2$ \\
\hline $\begin{array}{l}\text { CO2:Ability to identify and use appropriate parameters, assumptions, } \\
\text { and design criteria within the confines of the health and safety, ethics, } \\
\text { economics, environment and sustainability }\end{array}$ & $\mathrm{PO} 3$ \\
\hline CO3: Ability to perform manual design calculation based on required criteria & PO1 \\
\hline $\begin{array}{l}\text { CO4: Ability to conduct the design and preparation of drawings using the } \\
\text { relevant computer software(Excel, AutoCAD, and other design software) }\end{array}$ & PO6 \\
\hline $\begin{array}{l}\text { CO5: Ability to produce a report containing an executive summary, } \\
\text { introduction, distribution of tasks, concepts, design calculations, drawings for } \\
\text { bids, conclusion, etc. }\end{array}$ & PO7 \\
\hline CO6: Ability to present results verbally to the supervisor and examiner. & $\mathrm{PO} 7$ \\
\hline $\begin{array}{l}\text { CO7: Ability to perform tasks individually and to be an effective team } \\
\text { member. }\end{array}$ & PO8 \\
\hline CO8: Ability to prepare bills of quantities $(\mathrm{BQ})$ and the estimated cost & PO10 \\
\hline
\end{tabular}

Table 5. Evaluation of PO3 in the design report and presentation in the KKKH4254 course

\begin{tabular}{llllll}
\hline Design Report & & & & \\
\hline $\mathrm{CO}$ & $\mathrm{CO} 1$ & $\mathrm{CO} 2$ & $\mathrm{CO} 3$ & $\mathrm{CO} 4$ & $\mathrm{CO} 5$ \\
$\mathrm{PO}$ & $\mathrm{PO} 2$ & $\mathrm{PO} 3$ & $\mathrm{PO} 1$ & $\mathrm{PO} 6$ & $\mathrm{PO} 7$ \\
Weighted & 0.15 & 0.2 & 0.3 & 0.1 & 0.25 \\
Presentation (Internal Examiner) & & & & \\
$\mathrm{CO}$ & $\mathrm{CO} 1$ & $\mathrm{CO} 2$ & $\mathrm{CO} 3$ & $\mathrm{CO} 4$ & $\mathrm{CO} 5$ \\
$\mathrm{PO}$ & $\mathrm{PO} 2$ & $\mathrm{PO} 3$ & $\mathrm{PO} 1$ & $\mathrm{PO} 6$ & $\mathrm{PO} 7$ \\
Weighted & 0.25 & 0.25 & 0.1 & 0.2 & 0.2 \\
Presentation (External Examiner $1 \& 2)$ & & & & \\
$\mathrm{CO}$ & $\mathrm{CO} 1$ & $\mathrm{CO} 2$ & $\mathrm{CO} 3$ & $\mathrm{CO} 4$ & $\mathrm{CO} 5$ \\
$\mathrm{PO}$ & $\mathrm{PO} 2$ & $\mathrm{PO} 3$ & $\mathrm{PO} 1$ & $\mathrm{PO} 6$ & $\mathrm{PO} 7$ \\
Weighted & 0.25 & 0.25 & 0.1 & 0.2 & 0.2 \\
\hline
\end{tabular}

Each group is given architectural drawings and relevant information to adjust the ASPL requirements to the design components of these projects. This course meets the $8 \mathrm{CO}$ and $7 \mathrm{PO}$, as shown in Table 4. Overall 
evaluation of this course takes into consideration the report design, report bills of quantity (BQ); presentation of the project (evaluated by an internal and external examiner); and peer assessment. Internal and external examiners evaluate the students' performance in relation to PO3 involving the ASPL component by evaluating the students' design and presentation of project reports. Table 4 and 5 shows that the course includes components that relate to $\mathrm{PO} 3$ and $\mathrm{CO} 2$; it is therefore possible to measure the students' achievement in regard to ASPL components. Table 5 shows the breakdown of scoring for the $\mathrm{CO} 2$ and $\mathrm{PO} 3$ for each method of valuation determined by their weight measured. Weightage for $\mathrm{CO} 2$ and $\mathrm{PO} 3$ are fixed by 0.2 for the design of reports and 0.25 for presentation, respectively (internal examiner and external examiner).

\section{KKKW4024 Pollution Control}

This course is an elective course for both the JKAS program, and it is intended to give students the knowledge and understanding of the principles of preventing pollution from industrial activities, products that are environmentally friendly, and processing systems and manufacturers (Faculty of Engineering and Built Environment, 2009). Students need to understand the impact of waste from these activities and identify the methods of disposal, complete a product life cycle assessment, and understand the principles of sustainability. The ASPL component in this course relates to $\mathrm{CO} 1, \mathrm{CO} 2$, and $\mathrm{CO} 3$ with $\mathrm{PO}$. Students are divided into groups of 3-4, and each is assigned a different PBL project title involving environmental management case studies by industry/factory. Table 6 shows the relationship between COs and PO3 with the ASPL component. Assessments are based on the PBL project reports, which contributed $30 \%$ to the overall course marks.

Table 6. Course Outcomes (COs) and PO3 with ASPL component

\begin{tabular}{lll}
\hline Course outcomes, COs & $\begin{array}{l}\text { Programme } \\
\text { Outcomes, PO }\end{array}$ & $\begin{array}{l}\text { Evaluation } \\
\text { Method }\end{array}$ \\
\hline $\begin{array}{l}\text { CO1. Understand and learn the principles of pollution control of industrial and } \\
\text { construction activities, products that are environmentally friendly, and } \\
\text { processing and manufacturing activities to reduce environmental pollution. }\end{array}$ & PO3 & $\begin{array}{l}\text { PBL Project } \\
\text { Report }\end{array}$ \\
$\begin{array}{l}\text { CO2.Understand the principles associated with planning, design and } \\
\text { engineering analysis of some elements in the environment such as life cycle } \\
\text { assessment, environmental impact assessment and sustainable development. }\end{array}$ & PO3 & $\begin{array}{l}\text { PBL Project } \\
\text { Report }\end{array}$ \\
$\begin{array}{l}\text { CO3. Understand the responsibilities as an engineer and awareness of } \\
\text { environmental issues and the need for sustainable development. }\end{array}$ & PO3 & $\begin{array}{l}\text { PBL Project } \\
\text { Report }\end{array}$ \\
\hline
\end{tabular}

\section{Issues Highlighted for Improvement}

The comparative analysis of the three courses discussed in this paper related to the measurement of COs and POs, which emphasized the ASPL component. Inclusion of the ASPL component is considered to be the initial step to be taken to improve teaching and learning in engineering programs. The ASPL component is designed to ensure that students learn to apply the concept of environment and sustainability in their work. Issues to highlight include the following:

1) Should the PO3 change to limit the ASPL components in civil engineering design / environment as to adapt to all courses?

2) Measurement between the COs and POs are different between each course; should it be standardized for the entire course?

3) Each evaluation is very time consuming and requires comprehensive work in terms of domain, indicator, COs, and POs. Can this be implemented by the lecturers? Should certain courses be linked to a specific PO only?

4) Does the measurement of COs and POs accurately reflect student achievement as outlined in the objectives of the civil engineering program?

Regarding to improve CO and PO assessment, System of Assessment Plan for Educational Program (SP3P) was introduced in UKM to evaluate the CO and PO achievement starting with Semester 2 Session 20112012. Figure 2 shows how the SPS3 system is used for CO and PO assessment. 


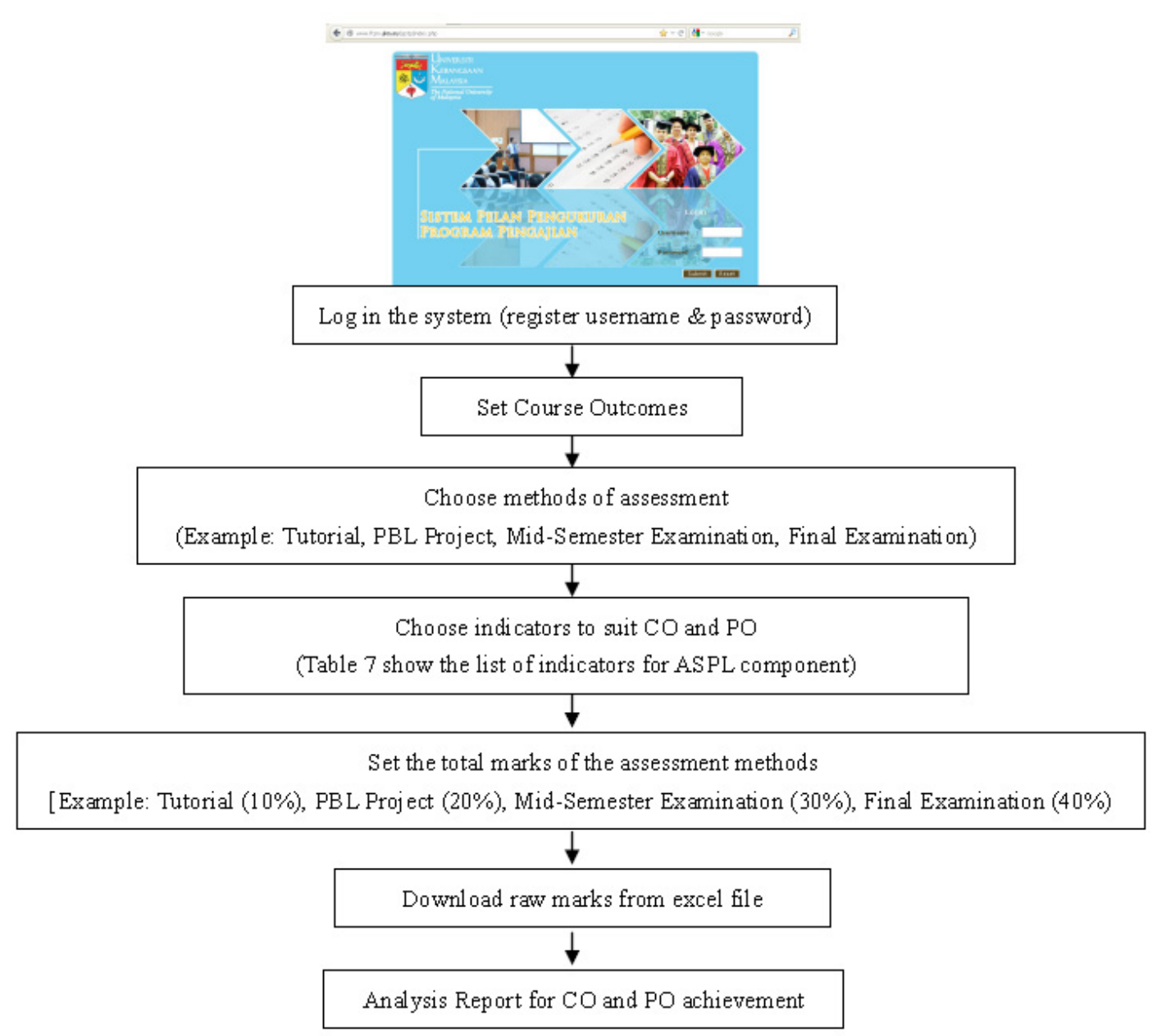

Figure 2. Steps to analyze $\mathrm{CO}$ and $\mathrm{PO}$ achievement using SP3P 
Table 7. Improvement of $\mathrm{PO} 3$ and list of indicators for ASPL component

\begin{tabular}{l}
\hline Improvement of ASPL Program Outcome \\
\hline PO3: Able to design \\
Civil and Structural/Environmental Engineering \\
Projects, systems or processes that meet \\
specified needs with appropriate consideration \\
for public health and safety, cultural, societal \\
and environmental including sustainable \\
development
\end{tabular}

\section{PO3 Statement:}

\section{Design/Development of Solutions:}

Design solutions for complex engineering problems and design systems, components or processes that meet specified needs with appropriate consideration for public health and safety, cultural, societal and environmental considerations.

\section{Environment and Sustainability:}

Understand the impact of professional engineering solutions in societal and environmental context and demonstrate knowledge of and need for sustainable development
CODE INDICATORS FOR ASPL COMPONENT

$3 \mathrm{C} 1$ Able to identify and/or recall and/or

remember and/or define and/or state design knowledge and concepts (to include social and environmental constraints including consideration of sustainable development) without necessarily understanding, using or changing it.

3C2 Able to understand, and/or explain, and/or discuss, and/or give example of design knowledge and concepts (to include social and environmental constraints including consideration of sustainable development) in own words.

3C3 Able to solve and/or demonstrate and/or understanding and/or illustrate knowledge and concepts (to include social and environmental constraints including consideration of sustainable development) learned to design Civil Engineering projects including new, concrete, abstract and/or complex problems.

3C4 Able to analyse and/or contrast and/or categorise and/or compare and/or differentiate knowledge and concepts (to include social and environmental constraints including consideration of sustainable development) in designing Civil Engineering works including new, concrete, abstract and/or complex projects.

3C5 Able to assess and/or judge and/or evaluate and/or interpret and/or justify and/or determine and/or conclude design solutions (to include social and environmental constraints including consideration of sustainable development) to Civil Engineering works including new, concrete, abstract and/or complex projects.

3C6 Able to combine and/or develop and/or generate and/or propose innovative design ideas and/or concepts (to include social and environmental constraints including consideration of sustainable development) for Civil Engineering projects including new, concrete, abstract and/or complex ones.

\section{Conclusion}

Based on the measurement of COs and POs for ASPL components in the three courses, it shows that there are differences in valuation carried out. Measurement of the ASPL component conducted in the KKKH4283 Sustainable Urban Planning course is through assignments and PBL project reports as outlined in PO4, KKKH4254 Course Design Project II is through the integration of project reports and presentations as outlined in PO3, while KKKW4024 Pollution Control courses are evaluated through the PBL reports project as outlined in PO3. The issue of accuracy and suitability on the performance measurement of the COs and POs for ASPL 
components in each course in JKAS needs to be discussed thoroughly with the full involvement of lecturers to develop the best measurement model for the Civil \& Structural Engineering Program and Civil \& Environmental Engineering Program.

\section{Acknowledgements}

The author would like to express appreciation to the UKM that allocated grants OUP-2012-126, PTS-2012-096 and PTS-2011-147 to conduct research on education and UKM campus sustainability. The grants provided have helped the researchers to engage students in learning activities to increase their concern for the environment and sustainable development. The author is also involved in research PTS-2011-144, which focuses on improving the measurement of learning outcomes for the $\mathrm{CO}$ and $\mathrm{PO}$ components of environmental and sustainable development in JKAS. This work supported by the Centre for Engineering Education Research, Faculty of Engineering and Built Environment, Universiti Kebangsaan Malaysia, Bangi, Selangor, Malaysia.

\section{References}

Bakar, A. A., Hussain, R. M. R., \& Idris, N. (2010). Driving culture change in Malaysian engineering education through EASTeL. Procedia Social and Behavioral Sciences, 9, 1537-1543. http://dx.doi.org/10.1016/j.sbspro.2010.12.361

Fakulti Kejuruteraan dan Alam Bina. (2009). Panduan Prasiswazah Fakulti Kejuruteraan dan Alam. Universiti Kebangsaan Malaysia.

Fakulti Kejuruteraan dan Alam Bina. (2010). Panduan Prasiswazah Fakulti Kejuruteraan dan Alam. Universiti Kebangsaan Malaysia. Retrieved from http://www.learningandteaching.info/learning/bloomtax.htm

Keene, M., \& Blumstein, D. T. 2010. Environmental education: A time of change, a time for change. Evaluation and Program Planning, 33, 201-204. http://dx.doi.org/10.1016/j.evalprogplan.2009.07.014

Kementerian Pengajian Tinggi. (2011). Pelan Strategik Pengajian Tinggi Negara. Retrieved form http://www.mohe.gov.my/portal/info-kemeterian-pengajian-tinggi/pelan-strategik.html

Zain, S. M., Basri, N. E. A., Basri, H., Elfithri, R., Tazilan, A. S. M., Ahmad, M., ... Khan, I. A. I. (2011). The Enhancement of Sustainable Humanitarian Mind Model by UKM Lestari Program. Procedia Social and Behavioral Sciences, 18, 666-673. http://dx.doi.org/10.1016/j.sbspro.2011.05.098 